\title{
GAMBARAN PENGETAHUAN, PENDIDIKAN DAN SOSIAL EKONOMI IBU YANG MEMILIKI BAYI DENGAN BERAT LAHIR RENDAH DI KECAMATAN SINGAPARNA KABUPATEN TASIKMALAYA TAHUN 2016
}

\author{
OLEH : \\ DR. SETIAWAN, SH,M.Kes \\ ANNISA RAHMIDINI, M.Keb
}

\section{A. ABSTRAK}

Salah satu penyebab kematian bayi yang angka kejadiannya paling tinggi adalah berat badan lahir rendah (BBLR). BBLR adalah bayi dengan berat lahir kurang dari 2500 gram tanpa memandang masa gestasi. Berat lahir rendah adalah berat bayi yang ditimbang dalam 1 jam setelah lahir. Berdasarkan data Puskesmas Singaparna pada tahun 2015 yang didapatkan di wilayah Puskesmas Singaparna terdapat 44 Bayi dengan BBLR.

Jenis penelitian yang digunakan adalah kuantitatif dengan metode deskriptif. Populasi dalam penelitian ini adalah ibu yang memiliki bayi dengan BBLR di wilayah Kecamatan Singaparna yaitu 34 orang. Cara Pengambilan Sampel dilakukan dengan cara total sampling dimana seluruh populasi dijadikan sampel. Instrumen dalam penelitian ini menggunakan kuesioner 10 pertanyaan untuk pengetahuan, 1 pertanyaan untuk pendidikan dan 1 pertanyaan untuk social ekonomi. Analisis data dalam penelitian ini adalah analisis univariat. Analisis ini menghasilkan distribusi frekuensi untuk menggambarkan tiap-tiap variabel yang akan diteliti.

Hasil penelitian menyatakan bahwa mayoritas pengetahuan ibu yang memiliki bayi dengan BBLR di Kecamatan Singaparna Kabupaten Tasikmalaya termasuk kategori kurang yaitu 64,7\%, pendidikan ibu yang memiliki bayi dengan BBLR adalah tamat SD yaitu 67,6\%, tingkat social ekonomi ibu yang memiliki bayi dengan BBLR termasuk kategori kurang dari UMR yaitu 76,5\%.

Diharapkan dapat meningkatkan upaya pencarian informasi untuk mendapatkan

pengetahuan yang baik tentang kebutuhan gizi selama hamil serta mencegah faktor resiko penyebab bayi dengan BBLR.

\section{Kata kunci : pengetahuan, pendidikan, sosial ekonomi, BBLR}




\section{A. LATAR BELAKANG}

Sebagian besar penyebab kematian bayi baru lahir adalah bayi berat badan lahir rendah (BBLR) 36\%, cacat bawaan 33\%, Asfiksia 31\% sedangkan penyebab lain kematian bayi baru lahir disebabkan oleh sepsis (infeksi sistemik), kelainan bawaan dan trauma persalinan(Dinkes, 2010). Penyebab kematian bayi dapat bermula dari masa kehamilan 28 minggu sampai hari ke 7 setelah persalinan (masa perinatal) (Profil Depkes RI, 2006).

Salah satu penyebab kematian bayi yang angka kejadiannya paling tinggi adalah berat badan lahir rendah (BBLR). BBLR adalah bayi dengan berat lahir kurang dari 2500 gram tanpa memandang masa gestasi. Berat lahir rendah adalah berat bayi yang ditimbang dalam 1 jam setelah lahir. World Health Organization (WHO) sejak tahun 1961 menyatakan bahwa semua bayi baru lahir yang berat badannya kurang atau sama dengan 2500 gram disebut low birth weight infant (bayi berat lahir rendah). Menurut WHO BBLR adalah bayi yang lahir dengan berat badan kurang dari 2500 gram. Angka kematian bayi menjadi indikator pertama dalam menentukan derajat kesehatan anak, karena merupakan cerminan dari status kesehatan anak saat ini. Secara statistik, angka kesakitan dan kematian pada nenonatus di negara berkembang adalah tinggi, dengan penyebab utama adalah berkaitan dengan BBLR (Puspitasari, 2011).

BBLR seringkali menyebabkan komplikasi, baik itu terjadi secara langsung setelah persalinan maupun untuk jangka panjang. Komplikasi jangka panjang antara lain gangguan perkembangan, gangguan pertumbuhan, gangguan penglihatan dan pendengaran, penyakit paru kronis dan sering masuk rumah sakit. (Subramanian, 2006).

Gangguan pertumbuhan yang biasa terjadi yaitu postur tubuh pendek, postur tubuh tinggi, berat badan kurang, makrosefalus dan mikrosefalus. Sedangkan gangguan perkembangan antara lain gangguan perkembangan motorik seperti gangguan gerakan dan sikap tubuh bayi , gangguan perkembangan bahasa seperti gangguan berbicara dan gagap serta gangguan emosi dan perilaku seperti fobia sosial dan autisme (Subramanian, 2006).

Berdasarkan data indikator kesehatan proporsi BBLR pada tahun 2015 berkisar antara $0,91 \%$ Faktor-faktor yang menyebabkan terjadinya BBLR antara lain kurangnya gizi pada ibu hamil, ibu hamil perokok, ibu hamil pekerjaberat, sosial 
ekonomi rendah dan faktor janin (Prawirohardjo, 2002). Joeharno (2008), menambahkan, bahwa BBLR juga dapat terjadi pada ibu dengan paritas tinggi. Ibu dengan paritas tinggi berisiko (50\%) melahirkan bayi dengan berat lahir yang rendah. BBLR merupakan masalah kesehatan yang cukup menonjol di Indonesia, karena pada bayi BBLR mempunyai angka mortalitas dan morbiditas yang tinggi.

Berdasarkan data Puskesmas Singaparna pada tahun 2015 yang didapatkan di wilayah Puskesmas Singaparna terdapat 44 Bayi dengan BBLR.

\section{B. METODOLOGI PENELITI}

Jenis penelitian yang digunakan adalah kuantitatif dengan metode deskriptif. Populasi dalam penelitian ini adalah ibu yang memiliki bayi dengan BBLR di wilayah Kecamatan Singaparna yaitu 34 orang yang terdistribusi berikut ini :

Tabel 1 Pembagian sampel berdasarkan wilayah

\begin{tabular}{|c|l|c|}
\hline No & \multicolumn{1}{|c|}{ Nama Desa } & Jumlah \\
\hline 1 & Singasari & 3 \\
\hline 2 & Singaparna & 6 \\
\hline 3 & Sukamulya & 6 \\
\hline 4 & Cipakat & 4 \\
\hline 5 & Sukaasih & 1 \\
\hline 6 & Cintaraja & 5 \\
\hline 7 & Cikunir & 3 \\
\hline 8 & Cikadongdong & $\mathbf{3 4}$ \\
\hline & \multicolumn{2}{|c}{ Jumlah }
\end{tabular}

Cara Pengambilan Sampel dilakukan dengan cara total sampling dimana seluruh populasi dijadikan sampel. Instrumen dalam penelitian ini menggunakan kuesioner 10 pertanyaan untuk pengetahuan, 1 pertanyaan untuk pendidikan dan 1 pertanyaan untuk social ekonomi. Analisis data dalam penelitian ini adalah analisis univariat. Analisis ini menghasilkan distribusi frekuensi untuk menggambarkan tiap-tiap variabel yang akan diteliti. 


\section{HASIL PENELITIAN \\ KARAKTERISTIK RESPONDEN}

\section{UMUR IBU}

\section{Tabel 2}

Distribusi frekwensi berdasarkan umur ibu

\begin{tabular}{|c|c|c|c|}
\hline No & Umur & F & \% \\
\hline 1 & $<20$ tahun & 12 & 35,3 \\
\hline 2 & $20-35$ tahun & 11 & 32,4 \\
\hline 3 & $>35$ tahun & 11 & 32,4 \\
\hline & Jumlah & $\mathbf{3 4}$ & $\mathbf{1 0 0}$ \\
\hline
\end{tabular}

Berdasarkan table 2 didapatkan bahwa mayoritas responden berusia < dari 20 tahun yaitu $35,3 \%$

\section{PEKERJAAN IBU}

Tabel 3

Distribusi frekwensi berdasarkan pekerjaan ibu

\begin{tabular}{|c|l|c|c|}
\hline No & \multicolumn{1}{|c|}{ Pekerjaan } & F & \% \\
\hline 1 & IRT & 21 & 61,7 \\
\hline 2 & Dagang & 3 & 8,8 \\
\hline 3 & Buruh & 10 & 29,5 \\
\hline & Jumlah & $\mathbf{3 4}$ & $\mathbf{1 0 0}$ \\
\hline
\end{tabular}

Berdasarkan table 3 didapatkan bahwa mayoritas pekerjaan ibu yang memiliki bayi dengan BBLR adalah ibu rumah tangga (tidak bekerja)

\section{PARITAS}

Tabel 4

Distribusi frekwensi berdasarkan Paritas

\begin{tabular}{|c|l|c|c|}
\hline No & Paritas & F & \% \\
\hline 1 & Primipara & 14 & 41,2 \\
\hline 2 & Multipara & 13 & 38,2 \\
\hline 3 & Grandepara & 7 & 20.6 \\
\hline & Jumlah & & $\mathbf{1 0 0}$ \\
\hline
\end{tabular}

Berdasarkan table 4.3 didapatkan bahwa mayoritas ibu yang memiliki bayi dengan BBLR, paritasnya adalah primipara yaitu 41,2\%. 


\section{PENGETAHUAN}

Tabel 5

Distribusi Frekwensi Tingkat Pengetahuan Ibu Yang Memiliki Bayi Dengan BBLR Di Kecamatan Singaparna Kabupaten Tasikmalaya Tahun 2016

\begin{tabular}{|c|l|c|c|}
\hline No & Pengetahuan & F & \% \\
\hline 1 & Baik & 12 & 35,3 \\
\hline 2 & Kurang & 22 & 64,7 \\
\hline & Jumlah & $\mathbf{3 4}$ & $\mathbf{1 0 0}$ \\
\hline
\end{tabular}

Berdasarkan table diatas didapatkan bahwa mayoritas pengetahuan ibu yang memiliki bayi dengan BBLR termasuk kategori kurang yaitu 64,7\%.

Distribusi jawaban responden berdasarkan pertanyaan :

\begin{tabular}{|c|c|c|c|c|c|c|c|}
\hline \multirow[t]{2}{*}{ No } & \multirow[t]{2}{*}{ Pertanyaan } & \multicolumn{2}{|c|}{ Benar } & \multicolumn{2}{|c|}{ Salah } & \multicolumn{2}{|c|}{ Jumlah } \\
\hline & & f & $\%$ & $\mathbf{f}$ & $\%$ & f & $\%$ \\
\hline 1. & $\begin{array}{l}\text { Bayi disebut dengan berat lahir } \\
\text { rendah apabila berat badan < dari } \\
2500 \text { gram }\end{array}$ & 27 & 79,4 & 7 & 20,6 & 34 & 100 \\
\hline 2. & $\begin{array}{l}\text { Pernikahan dini adalah bukan faktor } \\
\text { penyebab BBLR pada bayi }\end{array}$ & 19 & 55,8 & 15 & 44,2 & 34 & 100 \\
\hline 3. & $\begin{array}{l}\text { Kehamilan ganda / kembar adalah } \\
\text { salah satu penyebab bayi dengan } \\
\text { BBLR }\end{array}$ & 14 & 41,2 & 20 & 58,8 & 34 & 100 \\
\hline 4. & $\begin{array}{l}\text { Bayi dengan Berat lahir rendah tidak } \\
\text { berbahaya asalkan gerakan nya } \\
\text { lincah }\end{array}$ & 25 & 73,5 & 9 & 26,5 & 34 & 100 \\
\hline 5. & $\begin{array}{l}\text { Dampak Bayi dengan berat lahir } \\
\text { rendah adalah gangguan daya tahan } \\
\text { tubuh/ lebih mudah sakit }\end{array}$ & 27 & 79,4 & 7 & 20.6 & 34 & 100 \\
\hline 6. & $\begin{array}{l}\text { Status gizi ibu pada saat hamil dapat } \\
\text { menyebabkan bayi lahir dengan } \\
\text { BBLR }\end{array}$ & 23 & 67,6 & 11 & 32,4 & 34 & 100 \\
\hline 7. & $\begin{array}{l}\text { Salah satu upaya agar mencegah bayi } \\
\text { lahir dengan BBLR adalah } \\
\text { meningkatkan kebutuhan gizi pada } \\
\text { saat hamil. }\end{array}$ & 20 & 58,8 & 14 & 41,2 & 34 & 100 \\
\hline 8. & $\begin{array}{l}\text { Ibu hamil yang berusia kurang dari } \\
20 \text { tahun dapat menjadi faktor } \\
\text { penyebab bayi BBLR }\end{array}$ & 13 & 38,2 & 21 & 61,8 & 34 & 100 \\
\hline 9. & $\begin{array}{l}\text { Ibu hamil perlu mengkonsumsi zat } \\
\text { besi agar terhindar dari anemia dan } \\
\text { resiko bayi dengan BBLR }\end{array}$ & 12 & 35,3 & 22 & 64,7 & 34 & 100 \\
\hline 10. & $\begin{array}{l}\text { Agar menghindari memiliki bayi } \\
\text { dengan BBLR ibu hamil perlu } \\
\text { imunisasi saja }\end{array}$ & 24 & 70,6 & 10 & 29,4 & 34 & 100 \\
\hline & & & & & & & \\
\hline
\end{tabular}


Berdasarkan table diatas didapatkan bahwa mayoritas menjawab dengan benar defenisi BBLR dan dampak BBLR terhadap daya tahan tubuh bayi. Untuk pertanyaan yang dijawab salah mayoritas adalah tentang mengkonsumsi tablet zat besi untuk mencegah anemia sehingga dapat menyebabkan bayi lahir BBLR. Pertanyaan lain yang paling banyak dijawab salah adalah usia ibu kurang dari 20 tahun sebagai salah satu resiko bayi dengan BBLR.

\section{PENDIDIKAN}

Tabel 6

Distribusi Frekwensi Tingkat Penndidikan Ibu Yang Memiliki Bayi Dengan BBLR Di Kecamatan Singaparna Kabupaten Tasikmalaya Tahun 2016

\begin{tabular}{|c|l|c|c|}
\hline No & $\begin{array}{c}\text { Tingkat } \\
\text { pendidikan }\end{array}$ & F & \% \\
\hline 1 & Tamat SD & 23 & 67,6 \\
\hline 2 & Tamat SMP & 7 & 20,5 \\
\hline 3 & Tamat SMA & 4 & 11,9 \\
\hline & Jumlah & $\mathbf{3 4}$ & $\mathbf{1 0 0}$ \\
\hline
\end{tabular}

Berdasarkan table diatas didapatkan bahwa mayoritas pendidikan ibu yang memiliki bayi dengan BBLR adalah tamat SD yaitu $67,6 \%$.

\section{SOSIAL EKONOMI}

Tabel 7

Distribusi Frekwensi Tingkat tingkat social ekonomi ibu Yang Memiliki Bayi Dengan BBLR Di Kecamatan Singaparna Kabupaten Tasikmalaya Tahun 2016

\begin{tabular}{|c|c|c|c|}
\hline No & Social ekonomi & F & \% \\
\hline 1 & $<$ UMR & 26 & 76,5 \\
\hline 2 & $>$ UMR & 8 & 23,5 \\
\hline & Jumlah & $\mathbf{3 4}$ & $\mathbf{1 0 0}$ \\
\hline
\end{tabular}

Berdasarkan table diatas didapatkan bahwa tingkat social ekonomi ibu yang memiliki bayi dengan BBLR termasuk kategori kurang dari UMR yaitu 76,5\%. 


\section{E. PEMBAHASAN}

\section{Pengetahuan dan kejadian bayi dengan BBLR}

Berdasarkan hasil penelitian didapatkan bahwa mayoritas pengetahuan ibu yang memiliki bayi dengan BBLR termasuk kategori kurang yaitu 64,7\%.Pengetahuan adalah hasil tahu dan ini terjadi setelah orang melakukan pengindraan terhadap suatu objek tertentu. Penginderaan terjadi melalui panca indera manusia yakni: indera penglihatan, pendengaran, penciuman, rasa dan raba dengan sendiri. Pada waktu penginderaan sampai menghasilkan pengetahuan tersebut sangat dipengaruhi oleh intensitas perhatian persepsi terhadap objek. Sebagian besar pengetahuan manusia diperoleh melalui mata dan telinga (Notoatmodjo, 2003).

Pengetahuan merupakan domain dasar dalam pembentukan perilaku. Pegetahuan responden tentang BBLR dapat mempengaruhi perilaku ibu dalam memenuhi kebutuhan gizinya selama masa kehamilan. Selain itu pengetahuan ibu tentang faktor resiko pun yang harus dihindari agar tidak memiliki bayi dengan BBLR menjadi hal penting dipahami oleh seorang ibu hamil.

Berdasarkan distribusi pertanyaan didapatkan bahwa mayoritas menjawab dengan benar defenisi BBLR dan dampak BBLR terhadap daya tahan tubuh bayi. Untuk pertanyaan yang dijawab salah mayoritas adalah tentang mengkonsumsi tablet zat besi untuk mencegah anemia sehingga dapat menyebabkan bayi lahir BBLR. Pertanyaan lain yang paling banyak dijawab salah adalah usia ibu kurang dari 20 tahun sebagai salah satu resiko bayi dengan BBLR.

Ibu hamil di usia kurang dari 20 tahun merupakan kelompok resiko Penyebab bayi dengan BBLR. Ibu hamil usia kurang dari 20 tahun masih dalam tahapan tumbuh kembang. Sehingga nutrisi yang dikonsumsi ibu hamil dalam proses penyerapannya mengalami kompetisi antara ibu dan bayi nya. Selain itu salah satu resiko penyebab bayi BBLR adalah status gizi ibu hamil diantaranya adalah anemia. Anemia pada ibu hamil merupakan salah satu permasalahan gizi di Indonesia. Dampak anemia pada saat hamil salah satunya adalah resiko bayi dengan BBLR.

Hasil penelitian ini sesuai dengan hasil penelitian Setyaningsih pada tahun 2013 menunjukkan bahwa ada hubungan antara pengetahuan ibu bersalin tentang gizi dengan kejadian BBLR dengan nilai $\rho$ value 0,001 ( $\rho$ 
$<0,05)$. Semakin pengetahuan ibu tentang gizi ibu hamil kurang maka peluang mengalami kejadian BBLR semakin besar. Pada ibu hamil perlu mengatur pola makan dan merencanakan menu gizi seimbang. Dalam menu seimbang perbandingan antara protein, lemak dan karbohidrat dalam pengaturan menu harian harus senantiasa sesuai dengan kebutuhan tubuh, oleh karena itu diperlukan konsultasi dan bimbingan dengan ahli gizi. Status gizi ibu sebelum hamil juga cukup berperan penting dalam pancapaian gizi ibu saat hamil (Roosmeri, 2003).

Hasil penelitian sesuai dengan penelitian yang dilakukan oleh Cicik Handayani (2012), tentang hubungan pengetahuan ibu hamil tentang anemia kehamilan dengan kejadian anemia menunjukkan bahwa ada hubungan pengetahuan ibu hamil tentang anemia kehamilan dengan kejadian anemia,itu di sebabkan karena kurangnya asupan gizi yang di konsumsi oleh ibu saat hamil. Zat besi tersebut juga bisa di dapat dari tablet FE dan secara alami juga dapat di peroleh dari makanan. Karena kurangnya asupan gizi pada ibu saat hamil maka kemungkinan ibu mengalami anemia lebih besar.

Untuk meningkatkan pengetahuan ibu diperlukan berbagai upaya diantaranya uaya ibu untuk memperoleh informasi sebaik baiknya tentang kesehatan melalui kegiatan penyuluhan, konseling serta pencarian informasi melalui media cetak maupun elektronik.

\section{Tingkat pendidikan dan kejadian bayi dengan BBLR}

Berdasarkan hasil penelitian didapatkan bahwa mayoritas pendidikan ibu yang memiliki bayi dengan BBLR adalah tamat SD yaitu 67,6\%. Pengetahuan itu sendiri dipengaruhi oleh factor pendidikan formal. Pengetahuan sangat erat hubungannya dengan pendidikan. Dengan pendidikan yang tinggi maka orang tersebut akan semakin luas pula pengetahuannya. Akan tetapi perlu ditekankan, bukan berarti seseorang yang berpendidikan rendah mutlak berpengetahuan rendah pula.

Hal ini mengingat bahwa peningkatan pengetahuan tidak mutlak diperoleh dari pendidikan formal saja, akan tetapi dapat diperoleh melalui pendidikan non formal. Pengetahuan seseorang tentang sesuatu objek mengandung dua aspek positif dan objek yang diketahui, maka akan 
menimbulkan sikap yang makin positif terhadap objek tertentu. Menurut teori WHO (World Health Organization) yang dikutip oleh Notoatmodjo (2007), salah satu bentuk objek kesehatan dapat dijabarkan oleh pengetahuan yang diperoleh dari pengalaman sendiri.

Pendidikan ibu yang rendah berpengaruh terhadap pengetahuan yang dimiliki ibu, sehingga ibu terpengaruh dengan kebiasaan hidup yang tidak menunjang gaya hidup seperti makanan tidak bergizi (hanya berkarbohidrat, sedikit sayur, sedikit daging) dan banyaknya pantangan-pantangan makanan ibu hamil oleh peraturan adat nenek moyang. Makanan yang tidak bergizi membuat berat badan ibu hamil tidak mengalami peningkatan atau tetap dan mempengaruhi pertumbuhan janin, sehingga bayi yang dilahirkan mempunyai berat lahir dibawah berat normal (Wikipedia, 2010).

Hal ini memberikan gambaran bahwa tingkat pendidikan dasar memiliki resiko melahirkan bayi dengan BBLR dibandingkan tingkat pendidikan menengah, karena tingkat pendidikan dasar berpengaruh terhadap pengetahuan yang dimiliki ibu, sehingga ibu terpengaruh dengan kebiasaan hidup yang tidak menunjang gaya hidup seperti makanan tidak bergizi.

Hal ini sesuai dengan hasil penelitian Nining Hasanah tahun 2010 hasil ujiChi-Square didapatkan nilai $\mathrm{p}$ value 0,001, menunjukkan bahwa ada hubungan tingkat pendidikan ibu dengan kejadian bayi BBLR pada bayi secara statistik bermakna, dan makna hubungan tingkat pendidikan ibu dapat berpengaruh terhadap kejadian BBLR.

\section{Sosial ekonomi dengan kejadian bayi BBLR}

Berdasarkan hasil penelitian didapatkan bahwa tingkat social ekonomi ibu yang memiliki bayi dengan BBLR termasuk kategori kurang dari UMR yaitu $76,5 \%$.

Berat badan bayi baru lahir ditentukan oleh (faktor genetis) status gizi janin. Status gizi janin juga ditentukan oleh status gizi ibu waktu melahirkan dan keadaan ini dipengaruhi pula oleh status gizi ibu pada waktu konsepsi. Status ibu pada saat konsepsi dipengaruhi oleh keadaan sosial dan ekonomi ibu sebelum hamil. Status ekonomi jika yang bersangkutan hidup di bawah garis kemiskinan (keluarga prasejahtera), 
berguna untuk memastikan apakah ibu berkemampuan membeli dan memilih makanan yang bernilai gizi tinggi (Arisman, 2010).

Berg (1986) mengatakan bahwa pendapatan merupakan faktor yang paling menentukan kualitas dan kuantitas hidangan. Semakin banyak memperoleh uang berarti semakin baik makanan yang diperoleh. Dengan kata lain semakin tinggi penghasilan, semakin besar pula persentase dari penghasilan tersebut untuk membeli buah, sayuran dan beberapa jenis bahan makanan lainnya (Syafiq et al. , 2010).

Berg (1986) mengatakan bahwa pendapatan merupakan faktor yang paling menentukan kualitas dan kuantitas hidangan. Semakin banyak memperoleh uang berarti semakin baik makanan yang diperoleh. Dengan kata lain semakin tinggi penghasilan, semakin besar pula persentase dari penghasilan tersebut untuk membeli buah, sayuran dan beberapa jenis bahan makanan lainnya (Syafiq et al., 2010).

Untuk mendapatkan gizi yang baik tidak selalu diukur dari tingkat status ekonomi seseorang. Untuk mendapatkan makanan yang bergizi, tidak harus dalam harga tinggi. Banyak makanan yang didapat dengan harga murah, tetapi mempunyai nilai gizi yang tinggi. Hal ini mempunyai hubungan dengan pendidikan seseorang, bagaimana memilih makanan yang mengandung zat gizi, serta mengolah makanan tanpa menghilangkan zat gizi tersebut.

Sehingga akan dapat mensejahterakan seluruh anggota keluarganya dan yang lebih penting lagi bagaimana mengatur pengeluaran dalam rumah tangga, agar lebih bermanfaat untuk kesehatan keluarga.

\section{F. SIMPULAN DAN SARAN}

1. Simpulan

a. Mayoritas pengetahuan ibu yang memiliki bayi dengan BBLR di Kecamatan Singaparna Kabupaten Tasikmalaya termasuk kategori kurang yaitu 64,7\%.

b. Mayoritas pendidikan ibu yang memiliki bayi dengan BBLR di Kecamatan Singaparna Kabupaten Tasikmalaya adalah tamat SD yaitu 67,6\%.

c. Mayoritas Tingkat social ekonomi ibu yang memiliki bayi dengan BBLR di Kecamatan Singaparna Kabupaten Tasikmalaya termasuk kategori kurang dari UMR yaitu $76,5 \%$. 
2. Saran

a. Bagi ibu

Diharapkan dapat meningkatkan upaya pencarian informasi untuk mendapatkan pengetahuan yang baik tentang kebutuhan gizi selama hamil serta mencegah faktor resiko penyebab bayi dengan BBLR.

b. Bagi petugas kesehatan

Petugas kesehatan diharapkan dapat memberikan pelayanan kesehatan ibu dan anak secara maksimal dimulai dengan antenatal care, konseling atau penyuluhan yang berkesinambuangan terutama pada kelompok ibu hamil yang beresiko.

\section{G. DAFTAR PUSTAKA}

Asrining, dkk, 2013. Perawatan Bayi Risiko Tinggi. Jakarta: EGC.

Diana, 2008. Strategi Penanggulangan Gangguan Pertumbuhan Pada Anak Usia

Masuk Sekolah Di Kabupaten Karo Dengan Pendekatan Faktor Resiko [online].Tersedia:http://repository.usu.ac.id/bitstream/123456789/41494/4/ Chapter\%20II.pdf [diakses tanggal 23 Februari 2017].

Lisnawati, Lilis, 2013. Buku Praktis Kebidanan Komunitas. Jakarta: Trans Info Media

Mar'at, Samsunuwiyati, 2006. Psikologi Perkembangan. Bandung: PT Remaja Rosdakarya

Martika, 2012. Hubungan Berat Bayi Lahir Rendah (BBLR) Terhadap Keterlambatan Perkembangan Motorik Anak Usia Balita [online]. Tersedia:http://thesis.umy.ac.id/datapublik/t26273.pdf [diakses tanggal 11 Februari 2017]

Maryunani. A, 2011. Ilmu Kesehatasn Anak Dalam Kebidanan. Trans Info Media: Jakarta.

Mochtar, Rustam, 1998. Sinopsis Obstetri Fisiologi, Obstetri Patologi. Jakarta: EGC. Munthe, Maya Sari, 2015. Hubungan Pengetahuan Dengan Sikap Ibu Dalam Pemberian Stimulasi Pertumbuhan dan Perkembangan Neonatus [online]. Tersedia: http://repository.usu.ac.id/xmlui/bitstream/handle/123456789/ 47632/Chapter\%20II.pdf?sequence $=4$

Prawihardjo, Sarwono, 2002. Buku Acuan Nasional Pelayanan Kesehatan Maternal dan Neonatal. Jakarta: Yayasan Bina Pustaka Sarwono Prawihardjo.

Soetjiningsih, 2012. Tumbuh Kembang Anak. Jakarta: EGC.

Yuniarti, Sri, 2015. Asuhan Tumbuh Kembang Neonatus Bayi Balita dan Anak PraSekolah. Bandung: PT Refika Aditama. 
Nining Hasanah Faktor - Faktor Yang Berhubungan Dengan Kejadian Bayi Berat Lahir Rendah (Bblr) Di Ruang Bbrt Rsup Dr.Kariadi Semarang Tahun 2010

Hubungan Pengetahuan Ibu Bersalin Tentang Gizi Dengan Kejadian Bblr Di Puskesmas Pegandon Kabupaten Kendal Setyaningsih, Niken ${ }^{1)}$, Chicik Nirmasari ${ }^{2)}$, Auly Tarmali ${ }^{3)}$ 